\title{
ENGLISH COMMUNICATION NEEDS ANALYSIS OF THE OJEK ONLINE DRIVERS COMMUNITY IN BANYUWANGI REGENCY
}

\author{
${ }^{1}$ Abdul Halim, ${ }^{2}$ Sutami Dwi Lestari \\ ${ }^{1}$ English Educational Department, Faculty of Language and Art \\ PGRI University of Banyuwangi, East Jawa, Indonesia \\ halim_sid@yahoo.com \\ ${ }^{2}$ English Educational Department, Faculty of Language and Art \\ PGRI University of Banyuwangi, East Jawa, Indonesia \\ sutamidwilestari@gmail.com
}

\begin{abstract}
Online motorcycle taxi is a transportation mode that is being developed in the Banyuwangi regency. The development of regional tourism is the potential for foreign tourists as users of the services. This study aims to analyze the need for communication in English among online motorcycle taxi drivers in Banyuwangi. The study was conducted with a direct survey of 20 male drivers. The selection of respondents was done by using the snow ball method. Data were collected by means of a questionnaire containing 7 questions, each of which has 4 answer choices. Questionnaire data are grouped according to answers and analyzed according to existing theories. The results showed that online motorcycle taxi drivers need to improve communication skills in English for services to foreign tourists.
\end{abstract}

Keywords: ojek online; drivers; English communication

Transportation is a medium that is very needed today, because transportation can streamline work and help meet daily needs (Rifaldi, et. al, 2016). The availability of transportation services has a positive correlation with economic activity and development.Transportation services have an important role in smoothing the flow of goods and people, as well as helping to achieve an optimal allocation of economic resources (Qonitalillah, 2018). Collaboration of information technology with public transportation has had an impact on improving public services in the form of online public transportation (Qamar dan Aswari, 2018). Transportation is increasingly developt and modern along with the times, the development of transportation also affects the way of ordering and paying transactions for transportation services (Kemal, 2018).

Today there are the latest breakthroughs, namely online application based transportation innovations which supported by communication technology via smartphones (Marsusanti, et. al, 2018). Online-based transportation in Indonesia has become a promising alternative transportation in the society (Alfiqie, et. al, 2018). This trend is partly because users can choose the service or form of transportation they want (Yonas, 2018). The presence of 
online based transportation modes which in fact can provide solutions and answer various public concerns about public transportation services (Chan, et. al, 2017).

The convenience of the facilities obtained when using online transportation services makes people even more fond of them (Dewi dan Puspitasari, 2019). Currently, most people prefer to use online transportation to travel from one place to another or just to deliver goods or foods (Sudirman, et. al, 2020). Just only using a smartphone, online transportation will come to us and be ready to take us to our destination without having to negotiate prices (Setyaningsih, et. al, 2019).

Online-based transportation services are also very developed in Banyuwangi. One of the reasons for this is the development of tourism which is in great demand by domestic and foreign tourists. The number of foreign tourists shows a relatively significant increase. The number of visits was recorded at 66,963 people $(2013), 83,704$ people (2014) and 104,630 people (2015). This number shows an increase of $17.3 \%, 21.6 \%$, $27.1 \%$ respectively (Eston, et. al, 2016). The development of the number of visits can also be seen in the number of foreign tourists who stayed at the hotel in the 2015 - 2017 period, namely 59,597 people, 64,102 people and 71,271 people (Badan Pusat Statistik Kabupaten Banyuwangi). The number of foreign tourists shows the potential for online transportation services in Banyuwangi, including online motorcycle taxis. Transportation services must be able to provide the best service, because service quality has a significant and positive effect on tourist visits (Udiyana, et. al, 2108).

One form of online motorcycle taxi service is communication with service users. The communication behavior of online motorcycle taxi drivers can be seen in two forms, namely primary communication and secondary communication. The primary communication process is the communication carried out by the driver to the passengers directly, namely face to face when initially meeting to pick up passengers, on the way to delivering passengers and when arriving at the place of delivery of passengers. Meanwhile, the secondary communication process is a communication process carried out through the media or indirectly (Dewi, 2019). Online motorcycle taxi drivers have a unique choice of language when communicating with interlocutors on social media (Harared, 2018). This communication is one of the user satisfaction factors where service quality shows a very strong relationship with customer satisfaction (Rifaldi, et. al, 2016). Service quality and customer satisfaction will affect online motorcycle taxi customer loyalty (Sudirman, et. al, 2020).

Communication research among online motorcycle taxis is still focused on aspects of language registers. Research was conducted, among others, by Harared (2018) study the language selection of online motorcycle taxi drivers. Amiruddin (2019) study the communication patterns of online grab motorcycle taxi drivers on customer service in the city of Malang. Briskarisma (2019) study the online motorcycle taxi driver register on social media twitter. Dewi (2019) study the communication behavior of online motorcycle taxi drivers with their users. Fatoni (2020) study the Yogyakarta Gojek profession register with sociolinguistic analysis. Zeyn (2020) study the register of the online motorcycle taxi driver community in Semarang.

There are two ways communication patterns that are often carried out by online motorcycle taxi drivers in carrying out services (Amiruddin, 2019). Factors that influence the language register are place and situation, practicality in communicating, topics of conversation, environment, and keeping the conversation secret (Zeyn, 2020). There are more types of words in the noun form than in the verb form (Fatoni, 2020). Various new vocabulary or terms have appeared such as driver, scan, cancel, order and others (Harared, 2018). Language functions found in social media include emotive language, reference language, 
rhetorical language, and phatic language functions (Briskarisma, 2019).

The potential for foreign tourist visits in Banyuwangi at least requires practical ability to communicate in foreign languages, especially English. The results of the study on improving the English language skills of motorcycle taxi riders through the English dictionary on the Android application show that it is necessary to carefully formulate a foreign language mastery strategy (Santosa, et. al, 2018). The ability to communicate with drivers is very important so that passengers and potential passengers they meet are willing to follow directions (Rifai, et. Al, 2020). Research on female drivers concluded that there is almost no communication between drivers and foreign passengers (Mandiangan, et. al, 2019). A special form of learning is required for online motorcycle taxi drivers. This is necessary because the performance of online motorcycle taxi drivers can be influenced by knowledge sharing (Gunawan and Wardana, 2018).

During the Covid_19 pandemic, the tourism sector experienced a decline. Moreover, foreign tourist visits. There are many things that can still be done in the tourism sector during a pandemic or as a preparation for tourism in the new normal and post-pandemic era. In addition to health protocols, one of the tourism trends is solo travel tours, namely the use of individual transportation which is predicted to be higher than mass transport due to physical distancing (Paramita and Putra, 2020). Another prediction is a new digital-based tourism trend with the ease of financial transactions offered by digital payment systems (Maharani and Mahalika, 2020). The online motorcycle taxi transportation sector has the opportunity to predict tourism potential based on aspects of solo travel tours and digital transactions. This sector requires optimal service preparation, especially services to foreign tourist customers, one of which can be realized through foreign language communication skills.
Based on this background overview, with the opportunities and potential of foreign tourist service users, it is necessary to study the need for English communication among online motorcycle taxi's drivers in Banyuwangi regency.

\section{METHOD}

The research is arranged according to main frame in Figure 1. Banyuwangi Regency is one of the areas that develops its tourism potential. This development shows the development of interest in tourist visits, both domestic tourists and foreign tourists, especially in the period before the Covid_19 pandemic. One of the increasing needs for transportation is fulfilled by the presence of online motorcycle taxi modes of transportation. Service to customers will provide satisfaction which in general will have an impact on the income of online motorcycle taxi drivers and overall tourism development. For that, it is necessary to study the need to communicate in English among online motorcycle taxi drivers in Banyuwangi.

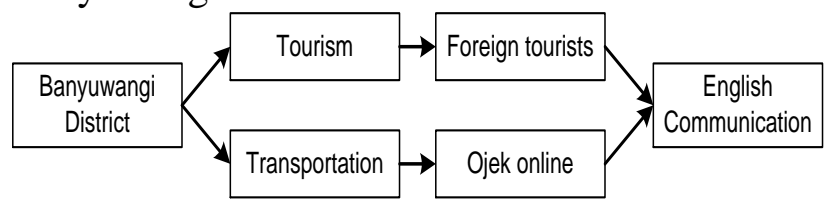

Figure 1. Framework concept

The research was conducted using a direct survey method in the online motorcycle taxi driver community. The location of the research was carried out in the regency area of Banyuwangi, particularly in Sub-district Banyuwangi. The sample of drivers were selected of 20 male drivers using the snow ball method. Data were collected using a closed questionnaire with 4 answer choices. The 7 questions in the questionnaire include work duration, the average number of foreign tourist users in a week (in the pre-pandemic period), the level of difficulty in communicating in English, solutions to overcome communication difficulties, the need to improve communication skills in English, efforts to improve the abilities that have been done and 
the learning methods that are considered the most appropriate. In addition, documentation was carried out at the time of data collection. The results of data collection are grouped according to the question items in the questionnaire. Data processing is done to get the average answer of the respondents. The results of data processing were then analyzed to obtain the level of communication needs in English among online motorcycle taxis in Banyuwangi regency.

\section{FINDINGS}

The number of respondents in the study was 20 people aged 21-55 years with an average age of 37.2 years. The length of work as an online motorcycle taxi driver is 1 to 2 years ( $45 \%$ of respondents) and more than 2 years (55\% of respondents). This length of work shows that all respondents had worked before the Covid_19 pandemic, where in the tourism sector, foreign tourist visits were still relatively high. Following are the results of the questionnaire data processing which are displayed in graphical form.

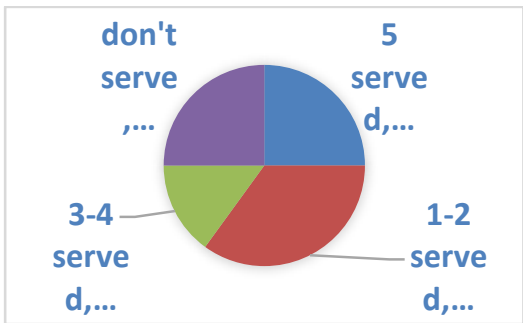

Figure 2. Graph of the number of foreign tourist users per week

The graph in Figure 2 shows that only $25 \%$ of respondents do not serve foreign tourist users every week. As many as $75 \%$ of respondents served foreign tourist users where the largest percentage $(35 \%$ of respondents) served 1-2 people per week.

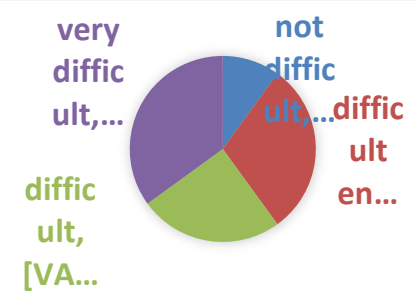

Figure 3. English communication difficulty
The graph in Figure 3 shows that the level of $90 \%$ of respondents stated that they had difficulty communicating in English. The largest percentage (35\% of respondents) stated that communication with foreign tourists in English is in the very difficult category.

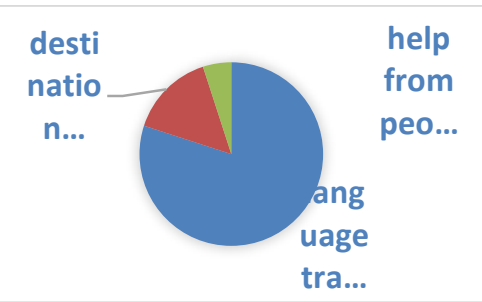

Figure 4. Communication difficulties solution

The graphic in Figure 4 shows that the solution taken to overcome communication difficulties is asking for help from people around them, using a destination map application and using a language translation application.

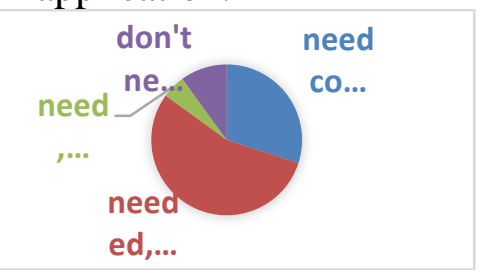

Figure 5. The level of communication needs

The graph in figure 5 shows that $90 \%$ of respondents need communication in English. As many as 55\% of respondents stated that they needed this communication skill. This supports the research of Rifai, et. al (2020) where communication skills are very important so that service users want to follow driver directions.

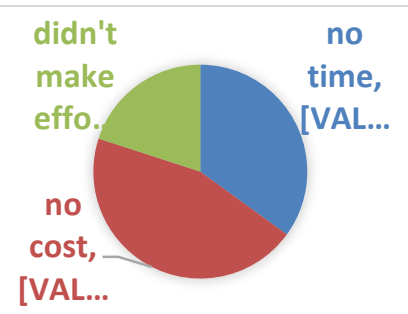

Figure 6.Constraints on improving communication skills

The graph in Figure 6 shows that the problem of increasing communication skills is due to the absence of time and no cost. 
Only $20 \%$ of respondents stated that they did not make efforts to improve their abilities.

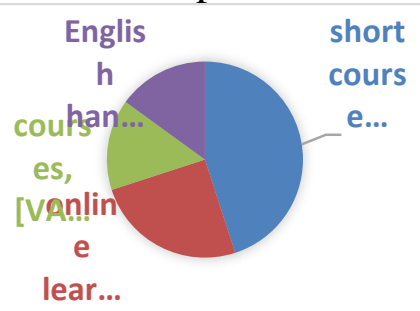

Figure 7.The desired method

The graph in Figure 7 shows that the desired methods to improve skills are courses, English handbooks, online learning and short course training. The choice of using pocket books in this case is in line with the research of Santosa, et. al (2018) which uses an English dictionary.

\section{DISCUSSION}

The research data shows that online motorcycle taxi drivers have difficulty communicating in English with foreign tourists who use their services. Communication difficulties are generally overcome by using destination map applications and language translation applications. The destination map application is used because the form of online motorcycle taxi service is to deliver people or goods to a place. The difficulties experienced are also in line with the research of Mandiangan, et. al (2019) where female drivers do not communicate with foreign tourist customers. Communication difficulties cause drivers not to carry out verbal communication in any form.

Another solution to communication difficulties is done with a language translation application. This is possible with smartphone devices that have features in Indonesian and have translation applications that can be used easily. But applications like this have the disadvantage of being unreliable for conversational form. However, smart-phones as the main communication device for drivers are a logical solution to overcome communication difficulties.

Drivers generally recognize the need to improve their English communication skills. However, efforts to increase face time constraints related to working hours as an obstacle. The cost factor is also an obstacle where the level of income earned is deemed unable to finance capacity building in the form of a learning process such as an English course. This means that drivers assume that capacity building efforts require costs that are not affordable for them financially. Meanwhile, the driver's income is strongly influenced by intense competition and a points system (Marsusanti, et. al, 2018).

The method of capacity building that drivers deem appropriate in the form of online learning and short course training is understandable because of the working time. Both of these methods can be done in between while they are waiting for customers or breaks. Online learning matches the smartphone used for work. Media items such as pocket books were also chosen because they could be read or studied at this time.

In general, the results show that online motorcycle taxi drivers who serve foreign tourists need English communication skills. Time and cost limitations prevent them from being able to improve their communication skills. An appropriate form of learning is a learning model that can adjust to the time constraints of drivers. Short course training is considered the method that best suits needs.

Drivers need assistance in efforts to improve English communication skills. Community service activities in the form of direct training can be carried out at the drivers' workplace. The learning media used is a pocket book. Activities like this are preparatory steps in dealing with potential changes in the post-pandemic period.

\section{CONCLUSION}

The results showed that online motorcycle taxi drivers need to improve communication skills in English for services to foreign tourists and they realize it. On-site training in the workplace can be done in the form of community service activities. 


\section{REFERENCES}

Alfiqie, M. S., Aknuranda, I., Wardani, N. H., (2018). Evaluasi Usability pada Aplikasi UBER Menggunakan Pengujian Usability. Jurnal Pengembangan Teknologi Informasi dan Ilmu Komputer 2(9), 2599-2606, http://j-ptiik.ub.ac.id

Amiruddin, M., (2019). Pola Komunikasi Driver Ojek Online Grabbike pada Pelayanan Customer di Kota Malang. Jurnal Penelitian Ilmiah Intaj 03(02), 26-49

Badan Pusat Statistik Kabupaten Banyuwangi, (2016).Kabupaten Banyuwangi Dalam Angka 2016, Banyuwangi regency in figures 2016, Retrieved from https://www.banyuwangikab.bps.go.id

Badan Pusat Statistik Kabupaten Banyuwangi, (2017).Kabupaten Banyuwangi Dalam Angka 2017, Banyuwangi regency in figures 2017, Retrieved from https://www.banyuwangikab.bps.go.id

Badan Pusat Statistik Kabupaten Banyuwangi, (2018).Kabupaten Banyuwangi Dalam Angka 2018, Banyuwangi regency in figures 2018, Retrieved from https://www.banyuwangikab.bps.go.id

Briskarisma, L., (2019). Register Driver Ojek Online di Media Sosial Twitter. Skripsi, Jurusan Bahasa dan Sastra Indonesia, Fakultas Bahasa dan Seni, Universitas Negeri Semarang

Chan, A., Maharani, M., Tresna, P. W., (2017). Comparison of User Experience on Go-Jek and Grab Mobile Apps (Study on PT. Go-Jek and PT. Grab Indonesia Consumer in DKI Jakarta). Jurnal AdBispreneur 2(2), 163-173

Dewi,N. K. S., \&Puspitasari, P. I., (2019). Tren Jasa Transportasi Online di Kalangan Mahasiswa Perguruan Tinggi Daerah Bali dan Solo Raya. Jurnal Ilmiah, Program Studi Ekonomi Pembangunan, Fakultas Ekonomi dan Bisnis, Universitas Sebelas Maret Surakarta

Dewi, S. C., (2019). Perilaku Komunikasi Driver Go-Ride Dengan Penggunanya (Studi Deskriptif Mengenai Perilaku Komunikasi Driver Go-ride Dalam Memberikan Kepuasan Pengguna Jasa Transportasi Online Go-Jek di Kota Bandung). Artikel Ilmiah, Program Studi Ilmu Komunikasi, Fakultas Ilmu Sosial dan Ilmu Politik, Universitas Komputer Indonesia, Bandung

Eston, A., Hananto, U. D., Soemarmi, A., (2016). Pengelolaan Potensi Pariwisata Dalam Pembangunan Kepariwisataan di Kabupaten Banyuwangi Menurut Undang-Undang Nomor 23 Tahun 2014 Tentang Pemerintahan Daerah. Diponegoro Law Review 5(2), 1-11, http://www.ejournal-s1.undip.ac.id/index.php/dlr/

Fatoni, A. S., (2020). Register Profesi Gojek Yogyakarta (Analisis Sosiolinguistik). Tsaqofiya: Jurnal Pendidikan Bahasa dan Sastra Arab 2(2), 67-83, DOI: $10.21154 /$ tsaqofiya.v2i2.29

Gunawan, H., \&Wardana, A. W., (2018). Knowledge Sharing Sebagai Mediasi Antara Employee Engagement Terhadap Kinerja Pengemudi Gojek di Yogyakarta. Briliant: 
Jurnal Riset dan Konseptual 3(4), 411-424, http://dx.doi.org/10.28926/briliant .v3i3.229

Harared, N., (2018). Realitas Komunikasi Pengendara Ojek Online di Jakarta: Studi Kasus Pemilihan Bahasa Driver Go-Send. Genta Bahtera, 4(2), 101-184

Kemal, N., (2018). Implementasi Promosi Paket Promo Transportasi Online (Go-Jek) Terhadap Loyalitas Konsumen. Jurnal Network Media 1(2)

Maharani, A., \&Mahalika, F., (2020). New Normal Tourism Sebagai Pendukung Ketahanan Ekonomi Nasional pada Masa Pandemi. Jurnal Kajian Lemhannas RI 8(2), 43-56

Mandiangan, P., Djumrianti, D., Hanifati, (2019). Online Transportation Technology and Women's Driver Communication Skills. Advances in Social Science, Education and Humanities Researchm volume 431, $3^{\text {rd }}$ Forum in Research, Science, and Technology (FIRST 2019): 141-145

Marsusanti, E., Susilawati, Nugraha,R., Koeswara, T. S. N., (2018). Faktor - Faktor yang Mempengaruhi Pendapatan Driver Gojek. Jurnal Swabumi 6(2), 128-132

Paramita, I. B. G., \&Putra, I. G. G. P. A., (2020). New Normal Bagi Pariwisata Bali di Masa Pandemi Covid 19. Pariwisata Budaya: Jurnal Ilmiah Pariwisata Agama dan Budaya 5(2), 57-65, Doi: 10.36275/mws

Qamar,N., \&Aswari, A., (2018). Healing or Hurting: Development of Highway Public Transportation Technology. Jurnal Dinamika Hukum 18(3), 319-328

Qonitalillah, C., (2018). Penggunaan Ojek Online di Kota Malang, Perspektif Hukum Islam. Skripsi, Jurusan Hukum Bisnis Syariah, Fakultas Syariah, Universitas Islam Negeri Maulana Malik Ibrahim, Malang

Rifai, M. Hidayat, Zuska, F., (2020). Character Education Conducted by Online Transportation Drivers for Each Customer (Case Study Ojek Online in Medan City). Advances in Social Science, Education and Humanities Research, volume 488, Proceedings of the $5^{\text {th }}$ Annual International Seminar on Transformative Education andEducational Leadership (AISTEEL 2020): 89-92

Rifaldi, Kadunci, Sulistyowati. (2016). Pengaruh Kualitas Pelayanan Transportasi Online Gojek Terhadap Kepuasan Pelanggan pada Mahasiswa/i Administrasi Niaga Politeknik Negeri Jakarta. Epigram 13(2), 121-128

Santosa, I., Ambarwati, D., Santosa, H., (2018). Peningkatan Kemampuan Berbahasa Inggris Pengendara "Gojek" Melalui Kamus Bahasa Inggris pada Aplikasi Android. Prosiding Seminar Nasional Ilmu Terapan (SNITER) 2018 - Unviersitas Widya Kartika, D08-1-4

Setyaningsih, E., Ismawan, E., Hidayat, T., (2019). Analisa Tingkat Kepuasan Pelanggan Transportasi Online Maxim di Balikpapan. j-sim: Jurnal Sistem Informasi 3(1), 3338

Sudirman, A., Sherly, Butarbutar, M., Nababan, T. S., Puspitasari, D., (2020). Customer Loyalty of Gojek Users Viewed from the Aspects of Service Quality and Consumer Satisfaction. Procuratio: Jurnal Ilmiah Manajemen 8(1), 63-73, http://www.ejournal.pelitaindonesia.ac.id/ojs32/index.php/PROCURATIO/index 
Udiyana, I. B. G., Kepramareni, P., Erlinawati, (2108). Pendekatan Dimensi Kualitas Pelayanan, Daya Tarik Wisata, Fasilitas, Biaya Perjalanan dan Promosi Pengaruhnya Terhadap Kunjungan Wisatawan pada Obyek Wisata Pantai Plengkung di Kabupaten Banyuwangi Propinsi Jawa Timur (Upaya Pemberdayaan Pengusaha Lokal Sektor Pariwisata). Jurnal Krisna: Kumpulan Riset Akuntansi 10(1), 102-108, https://ejournal.warmadewa.ac.id/index.php/krisna

Yonas, Y. A., (2018). Strategi Komunikasi Komunitas Keluarga Besar Gojek Grup Sepuluh dalam Membentuk Persepsi Positif para Pengguna dan Calon Pengguna Jasa Ojek Online di Yogyakarta (Studi Deskripsi Kualitatif tentang Strategi Komunitas Komunikasi Keluarga Besar Gojek Grup Sepuluh dalam Membentuk Persepsi Positif para Pengguna dan Calon Pengguna Jasa Ojek Online di Yogyakarta). Skripsi, Program Studi Ilmu Komunikasi, Sekolah Tinggi Pembangungan Masyarakat Desa “APMD”, Yogyakarta

Zeyn,E. M. A., (2020).Register Komunitas Driver Ojek Online di Semarang: Studi Kasus Driver Grab Bike. Skripsi, Fakultas Ilmu Budaya, Universitas Diponegoro Semarang 